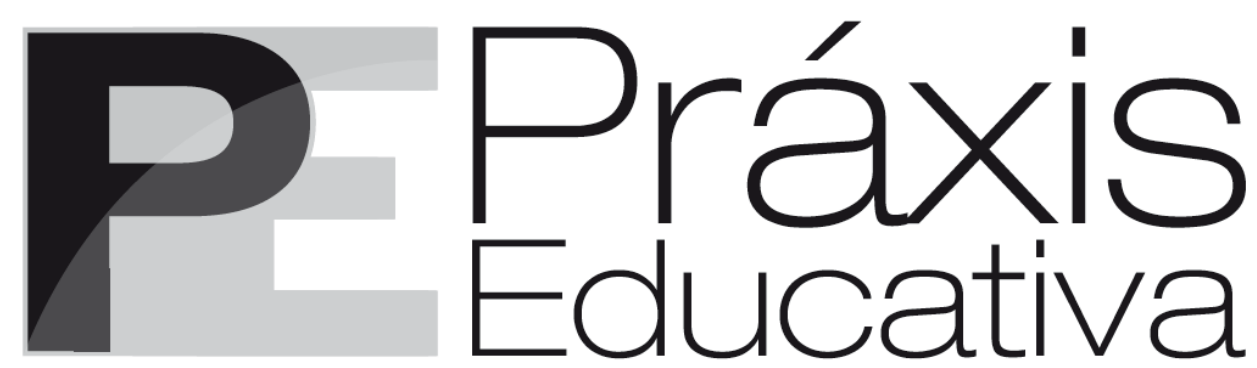

ISSN 1809-4031

elSSN 1809-4309

http://dx.doi.org/10.5212/PraxEduc.v.14n3.021

\title{
Feminismos e redes sociais: (in)ações e (im)possibilidades de jovens de periferia urbana
}

\section{Feminisms and social networks: (in)actions and (im)possibilities of young people from urban periphery}

\section{Feminismos y redes sociales: (in)acciones e (im)posibilidades de jóvenes de la periferia urbana}

Juliana Vargas*

Karla Saraiva* $^{* *}$

Resumo: Este artigo propõe-se a investigar a relação de um grupo de alunas de uma escola da rede pública de Porto Alegre (Rio Grande do Sul) com o feminismo. A pesquisa foi desenvolvida por meio de grupos de discussão e as análises apoiam-se nos Estudos Culturais, Estudos Feministas e Estudos de Juventude. Foi possível perceber a preocupação dessas jovens com a violência contra as mulheres, externando apoio ao feminismo, porém sem uma identificação com movimentos organizados. Apesar disso, as participantes indicam a importância de fomento do feminismo por meio de redes sociais em articulação com eventos presenciais e expressam o desejo de que o tema seja inserido nas atividades escolares. A pesquisa permitiu compreender que as ideias feministas vêm se alastrando entre mulheres jovens, mesmo sem que elas acessem de modo sistemático discussões sobre o tema.

Palavras-chave: Feminismo. Juventude. Redes sociais.

\begin{abstract}
This article proposes to investigate the relation of a group of students from a public school in Porto Alegre (Rio Grande do Sul, Brazil) and feminism. The research was developed through discussion groups and the analyzes are based on Cultural Studies, Feminist Studies, and Youth Studies. It was possible to perceive the concern of these girls with violence against women, expressing support for feminism, but without identification with organized movements. In spite of this, the participants indicate the importance of fomenting feminism through social networks in articulation with face-to-face events and express the desire that the theme be inserted in school activities. The research made it possible to understand that feminist ideas are spreading among young women, even though they do not systematically access discussions on the subject.
\end{abstract}

Keywords: Feminism. Youth. Social networks.

\footnotetext{
* Professora da Universidade Luterana do Brasil. Doutora em Educação pela Universidade Federal do Rio Grande do Sul. E-mail: <juliana.vargas@ulbra.br>. ORCID: https://orcid.org/0000-0002-2959-7889

** Professora da Universidade Luterana do Brasil. Doutora em Educação pela Universidade Federal do Rio Grande do Sul. E-mail: <profa.karla.saraiva@gmail.com>. ORCID: https://orcid.org/0000-0002-2105-0619
} 
Resumen: Este artículo se propone a investigar la relación de un grupo de alumnas de una escuela de la red pública de Porto Alegre (Rio Grande do Sul, Brasil) con el feminismo. La investigación se desarrolló por medio de grupos de discusión y los análisis se apoyan en los Estudios Culturales, Estudios Feministas y Estudios de Juventud. Fue posible percibir la preocupación de esas jóvenes con la violencia contra las mujeres, exteriorizando apoyo al feminismo, pero sin una identificación con movimientos organizados. A pesar de esto, las participantes indican la importancia de fomento del feminismo por medio de redes sociales en articulación con eventos presenciales y expresan el deseo de que el tema sea incluido en las actividades escolares. La investigación permitió comprender que las ideas feministas se vienen extendiendo entre mujeres jóvenes, incluso sin que ellas busquen de modo sistemático discusiones sobre el tema.

Palabras claves: Feminismo. Juventud. Redes sociales.

\section{Introdução}

Neste artigo, derivado de uma pesquisa sobre culturas juvenis contemporâneas de periferias urbanas nas cidades de Porto Alegre (RS) e Canoas (RS), buscamos analisar as narrativas de um grupo de alunas, com idades entre 15 e 16 anos, sobre feminismos na Contemporaneidade, suas conexões com o espaço virtual e os atravessamentos de práticas feministas em suas vidas cotidianas ${ }^{1}$. Para tanto, buscamos aporte nas perspectivas dos Estudos Culturais em Educação, dos Estudos Feministas e dos Estudos de Juventude. Compreendemos, assim, o conceito de juventude como uma categoria plural, distante das classificações etárias e das descrições biológicas como modos únicos para descrevê-la e contextualizá-la, tal como abordam autores como Feixa, Fernández-Planells e Figueras-Maz (2016) e Dayrell (2007).

Iniciamos por uma breve historicização dos movimentos feministas visando a constituir um pano de fundo para as análises. Nesse movimento, damos destaque às pautas do referido movimento na atualidade, bem como sua relação com as tecnologias digitais. Posteriormente, apresentamos os marcos metodológicos que pautam o presente estudo e analisamos as narrativas das alunas, produzidas por meio de um grupo de discussão, sobre os femininos na Contemporaneidade. Finalizamos o artigo com algumas considerações finais, conclusões contingentes que apontam para outras possibilidades investigativas.

\section{De feminismos e redes}

De acordo com Pinto (2010), a primeira onda do feminismo teria acontecido a partir do final do século XIX, estendendo-se até as primeiras décadas do século XX. O movimento, que se iniciou na Inglaterra e depois se expandiu para outros países, reivindicava a ampliação de direitos para as mulheres. Tinha cunho liberal e não pretendia uma mudança social mais ampla, focandose apenas na igualdade de direitos. Entre as reivindicações, a mais conhecida é a de direito ao voto, tornando estas pioneiras conhecidas como suffragettes. No entanto, outras reivindicações foram feitas durante o período, a exemplo das lutas para maior acesso à educação, à possibilidade do exercício da docência e às condições dignas de trabalho.

\footnotetext{
1 As alunas participam da pesquisa "Juventudes contemporâneas de periferia e a sala de aula: discursos, tensionamentos e possibilidades", aprovada pelo Edital Universal 2016/1, do CNPQ, sob o número 428136/2016-8 e aprovada pelo Comitê de Ética da Universidade Luterana do Brasil sob o número - 91676618.7.0000.5349.
}

Práxis Educativa, Ponta Grossa, v. 14, n. 3, p. 1188-1209, set./dez. 2019 Disponível em: <http://www.revistas2.uepg.br/index.php/praxiseducativa> 
Apesar da ênfase do movimento feminista naquele momento centrar-se na questão do voto, vale notar que o que hoje é chamado de interseccionalidade ${ }^{2}$ já estava presente na época. A par da luta pelo voto, essa primeira onda também abriga uma vertente abolicionista. Entretanto, as feministas brancas colocaram-se contra esse movimento, pois pensavam que a libertação dos escravos traria retrocessos na sua condição. As feministas negras desta época foram praticamente apagadas (RIBEIRO, 2017). Além das feministas negras, essa primeira onda também comportou um feminismo operário, baseado nas ideias de Marx (FURIOSA, 2018). Desse modo, apesar de ter uma denominação singular, naquele momento, eram interesses de grupos diversos que constituíam as reivindicações, estabelecendo o feminismo como um movimento heterogêneo e plural, conforme destaca Meyer:

Basicamente, naquele período histórico, se poderia fazer referência a um feminismo liberal ou burguês, que se engajou mais na luta pelo direito ao voto e ao ensino superior, a um feminismo que se aliou aos movimentos socialistas que lutavam pela formação de sindicatos e por melhores condições de trabalho e salário, e a um feminismo anarquista que articulou à agenda pelo direito à educação questões como o direito de decidir sobre o próprio corpo e sua sexualidade. O movimento é, pois, desde essas origens, multifacetado. (MEYER, 2003, p. 12).

Esse movimento chegou também ao Brasil, resultando na fundação da Federação Brasileira pelo Progresso Feminino

[...] em 9 de agosto de 1922, por Bertha Maria Júlia Lutz, com sede no Rio de Janeiro. A entidade, cujo embrião foi a Liga pela Emancipação da Mulher, lutou pela igualdade de direitos entre homens e mulheres, pelo acesso das mulheres a educação e ao mercado de trabalho, e contribuiu para a conquista do voto feminino [...]. (BRASIL, 2018, n. p.).

Vale lembrar, porém, que a luta pelo direito ao voto era organizada por "mulheres cultas e de classes dominantes", apoiadas pela classe política brasileira; dessa forma, representava "[...] um feminismo bem-comportado, [...] não buscando agregar nenhum tipo de tema que pudesse pôr em xeque as bases da organização das relações patriarcais" (PINTO, 2003, p. 26). O direito ao voto foi garantido pelo Código Eleitoral de 1932 e incorporado à Constituição de 1934. Em 1935, o voto tornou-se obrigatório no país para as mulheres que desempenhavam atividades remuneradas. Contudo, foi somente em 1965 que o voto feminino foi igualado às condições do voto masculino (BRASIL, 2013).

O feminismo perdeu força na década de 1930 e só seria significativo novamente nos anos 1960. Essa segunda onda surge em uma época de diversos movimentos contestatórios. O movimento hippie nos Estados Unidos posicionava-se contra a Guerra do Vietnam e, de modo mais geral, contra os valores dominantes da época (MANRIQUE, 2017) e tinha como lema "paz e amor". Em maio de 1968, eclode, na França, um movimento iniciado por estudantes universitários, que logo se aliam a operários, que consegue uma série de avanços tanto nos direitos trabalhistas quanto no sistema universitário, com efeitos culturais que se estendem para além das fronteiras desse país (THIOLLENT, 1998). Também é nessa década que Martin Luther King e Malcom X, entre outros, lideram movimentos que exigiam direitos civis para os negros. É a época de surgimento dos Beatles e dos Rolling Stones, com sua musicalidade rebelde. Esses movimentos contestatórios deram-se em um momento em que as sociedades europeias e norteamericana passavam por um momento de grande prosperidade, reduzindo as pressões

\footnotetext{
2 Interseccionalidade é um conceito cunhado por Crenshaw (1989) para mostrar que as desigualdades são multidimensionais e que as diversas formas de opressão e dominação e se cruzam e se articulam de diferentes formas. Embora a forma mais conhecida da interseccionalidade esteja associada ao feminismo negro, outros fatores também são considerados. Sexismo e racismo são ainda atravessados por homo e transfobia, gordofobia, capacitismo, entre outras formas de discriminação.
}

Práxis Educativa, Ponta Grossa, v. 14, n. 3, p. 1188-1209, set./dez. 2019 Disponível em: <http://www.revistas2.uepg.br/index.php/praxiseducativa > 
econômicas sobre os indivíduos, permitindo pensar em uma reorganização social com enfraquecimento das normas disciplinares e crescimento das aspirações de uma vida com mais liberdade (LIPOVETSKY, 2004).

É nesse contexto que a segunda onda feminista emerge. Nos anos de 1960, a pílula anticoncepcional passou a ser acessível a muitas mulheres. Em 1963, Betty Friedan lançou $A$ mistica feminina, que seria considerada a obra mais importante para esse novo feminismo. As reivindicações desse movimento foram além dos direitos civis e das questões trabalhistas das primeiras feministas, sem esquecê-las. Elas desejavam salários iguais e participação na vida pública, mas também lutavam para transformar as relações entre homens e mulheres. Apontavam para formas de dominação que extrapolavam as relações de classe, expondo relações de poder exercidas pelos homens sobre as mulheres, residindo aí sua originalidade. As mulheres da segunda onda queriam liberdade para decidir sobre sua vida e seu corpo (PINTO, 2010). Nessa segunda onda, o feminismo reconheceu a especificidade das diversas mulheres, porém apontava que todas são oprimidas com base no sexo. Veio daí um de seus bordões: "o pessoal é político". Com sua ênfase na dominação masculina, a segunda onda afastou-se das ideias liberais e aproximou-se das ideias marxistas e, ainda, também do campo teórico da psicanálise (MEYER, 1996)

Assim, o feminismo da segunda onda procurou compreender, por meio de articulações teóricas, os processos de invisibilidade e subordinação que as mulheres vivenciaram ao longo da História. Tais processos sustentaram (e ainda sustentam) a idealização de comportamentos femininos, a naturalização de uma menor remuneração salarial e de atos de violência e discriminação para com as mulheres, como destaca Meyer:

\begin{abstract}
A segunda onda remete ao reconhecimento da necessidade de um investimento mais consistente em produção de conhecimento, com o desenvolvimento sistemático de estudos e de pesquisas que tivessem como objetivo não só denunciar, mas, sobretudo compreender e explicar a subordinação social e a invisibilidade política a que as mulheres tinham sido historicamente submetidas. (MEYER, 2003, p. 12).
\end{abstract}

Esse período foi marcado pela insatisfação de mulheres negras serem representadas por mulheres brancas, tornando a vertente feminismo negro independente, e, também, pelo surgimento de um feminismo lésbico (FURIOSA, 2018).

Vale destacar que o Brasil vivia, desde 1964, sob a égide de uma ditadura civil-militar, o que dificultou o surgimento de movimentos libertários no país. Entretanto, mesmo em um ambiente autoritário e fortemente repressivo, é possível apontar a existência de contestações. Por um lado, uma resistência direta à ditadura militar por parte de uma gama de grupos de esquerda, alguns deles apelando para a luta armada (COIMBRA, 2001). Por outro lado, ocorreu uma série de manifestações artísticas e culturais de caráter contestatório e combativo, em especial no período entre 1964 e 1968, quando recrudesce a repressão. Nesses anos, apareceu o movimento musical conhecido como tropicalismo, surgiram grandes festivais de música que se caracterizavam por consagrar músicas de protesto, consolidou-se o Cinema Novo e a antropofagia de José Celso Martinez no Teatro Oficina (DEL ROIO et al., 2008). Entretanto, mesmo com a dura repressão, ainda houve algumas manifestações transgressoras importantes nos anos de 1970, sendo possível destacar o aparecimento do grupo musical Secos \& Molhados e o grupo teatral Dzi Croquettes. Essas manifestações, apesar de não confrontarem diretamente o governo militar, desafiavam as normas e a moral vigente.

Esse ambiente repressivo fez com que o feminismo dos anos de 1960 chegasse ao Brasil apenas na década de 1970. Entretanto, é importante notar que, nos anos 1960, a atriz Leila Diniz, com seu comportamento transgressor, mesmo sem assumir um discurso feminista, deu uma 
contribuição importante para a liberação das mulheres no país. Pouco politizada, foi acusada de alienada pela esquerda e de vagabunda pela direita. Suas atitudes não obtiveram nem mesmo aprovação das feministas da época, tendo em vista que consideravam que seu comportamento a tornava apenas uma mulher disponível para os homens. Em um ambiente fortemente marcado pela luta contra a ditadura, as atitudes livres e sem preocupação em relação a uma política governamental de Leila impediram, na época, de reconhecer sua contribuição para o feminismo (MEDEIROS, 2016).

Pode-se perceber, entre as décadas de 1970 e início dos anos de 1980, uma maior apropriação das mulheres sobre o espaço midiático, possivelmente por efeito de transformações sociais ocorridas naquele período, como a declaração do Ano Internacional da Mulher, em 1975. Em termos de cultura popular, é importante notar que o Brasil assistia à minissérie Malu Mulher (1979), que retratava o cotidiano de uma mulher divorciada, e que determinadas canções passaram a descrever a figura feminina como protagonista de suas escolhas - Olhos nos olhos (Chico Buarque), Comegar de novo (Ivan Lins e Vitor Martins) e a Maria, Maria, (Milton Nascimento) são alguns exemplos.

Para os militares, as feministas eram moral e politicamente perigosas (PINTO, 2010). No entanto, também a esquerda não via o movimento com bons olhos. Pode-se depreender que o movimento feminista brasileiro da chamada segunda onda do feminismo se iniciou na Europa, por meio de mulheres brasileiras exiladas. Ele surgiu sob a desconfiança dos homens exilados, que consideravam um desvio na luta contra a ditadura, apesar de muitos deles serem companheiros das exiladas. Contudo, essa segunda onda do feminismo só se consolidou, no Brasil, nos anos de 1980, com o processo de redemocratização. Surgiram diversos grupos organizados por mulheres predominantemente brancas, de classe média e intelectualizada, porém com interfaces com as classes populares, que buscavam, além de direitos mais igualitários entre homens e mulheres, condições dignas de vida para os moradores das periferias urbanas. As lutas aqui se dispersavam em temas diversos, como "[...] violência, sexualidade, direito ao trabalho, igualdade no casamento, direito à terra, direito à saúde materno-infantil, luta contra o racismo, opções sexuais" (PINTO, 2010, p. 17). Entre as vitórias dessa época, cabe destacar a criação do Conselho Nacional da Condição da Mulher (CNDM), em 1984, e a inclusão na Constituição de 1988 de uma série de direitos (PINTO, 2010).

Nos anos de 1990, emergiu o que é considerada a terceira onda do feminismo, visando superar limitações do estágio anterior. Se a originalidade da segunda onda estava em problematizar as relações de dominação dos homens sobre as mulheres, é possível afirmar que a originalidade da terceira onda é a desnaturalização das características femininas. A terceira onda fundamenta-se fortemente no pensamento pós-estruturalista. A ideia de interseccionalidade, introduzida em 1989 por Creenshaw, vai aprofundar o feminismo identitário (FURIOSA, 2018). Esse conceito "[...] permite-nos enxergar a coalisão das estruturas, a interação simultânea das avenidas identitárias, além do fracasso do feminismo em contemplar mulheres negras, já que reproduz o racismo" (AKOTIRENE, 2018, p. 14).

A terceira onda faz a defesa radical da multiplicidade de modos de vivenciar a experiência de gênero, criticando padrões que limitam quaisquer formas de exercício da sexualidade feminina e da própria constituição da feminilidade. Se a segunda onda tinha posições firmes contra a pornografia e a prostituição, agora esses temas passaram a ser problematizados e aceitos por boa parte das militantes, que passam a considerá-los como práticas com potencial libertador (TOMAZETTI; BRIGNOL, 2015). Saem do entendimento de práticas de violência à mulher e passam a ser tomadas como possiblidades de exercício da sexualidade.

Práxis Educativa, Ponta Grossa, v. 14, n. 3, p. 1188-1209, set./dez. 2019 Disponível em: <http://www.revistas2.uepg.br/index.php/praxiseducativa> 
Ao contrário de suas precursoras da segunda onda - e até da primeira onda -, que lutavam para quebrar estereótipos associados à mulher, as feministas de terceira onda se apropriaram desses estereótipos, de condutas e de símbolos de feminilidade. Em outras palavras, elas pegaram os sutiãs, os batons e os saltos que suas precursoras haviam abandonado e os colocaram de volta, em defesa da liberdade individual de cada mulher. (FURIOSA, 2018, n.p.).

Essa terceira onda reapropria-se de termos misóginos e os transforma em plataformas de luta, como é o caso da Marcha das Vadias (TOMAZETTI; BRIGNOL, 2015) ${ }^{3}$. Duas obras importantes para a constituição da terceira onda são o Manifesto Ciborgue, obra de Donna Haraway, lançada em 1985, e Problemas de gênero, de autoria de Judith Butler, publicada em 1990. No Brasil, no período conhecido como a terceira onda, ocorre um importante avanço: a aprovação da Lei Maria da Penha, no ano de 2006. Essa Lei foi considerada pela Organização das Nações Unidas (ONU) como uma das três melhores legislações do mundo para proteção das mulheres, mas também há o reconhecimento das limitações em sua aplicação (ONUBR, 2010).

Atualmente, discute-se se já estaríamos vivenciando uma quarta onda do feminismo ou se ainda estaríamos na terceira onda. De acordo com Furiosa (2018, n.p.), “[...] parte da academia já afirma existir uma quarta onda do feminismo, caracterizada principalmente pelo uso maciço das redes sociais para organização, conscientização e propagação dos ideais feministas". O que marcaria essa nova onda é uma preocupação crescente com a violência contra a mulher e o uso de redes sociais, tais como Facebook, Twitter, Instragram e Youtube como espaços para a circulação de pautas e ações sobre o tema. Apesar de não haver consenso no mundo acadêmico acerca da emergência de uma quarta onda no feminismo, Hollanda (2018), importante intelectual feminista, posiciona-se claramente a favor dessa ideia:

Sou uma feminista da terceira onda. Meu jeito e minhas estratégias não são as que vejo em cena aberta. [...]. O feminismo hoje não é o mesmo da década de 1980. [...]. Vejo claramente a existência de uma nova geração política, na qual se incluem as feministas, com estratégias próprias, criando formas de organização desconhecidas para mim, autônomas, desprezando a mediação representativa, horizontal, sem lideranças e protagonismos, baseadas em narrativas de si, de experiências pessoais que ecoam coletivas, valorizando mais a ética ${ }^{4}$ do que a ideologia, mais a insurgência do que a revolução. (HOLLANDA, 2018, p. 12).

Para essa pesquisadora, a quarta onda se iniciou no Brasil em 2015. Segundo ela:

Há pouquíssimo tempo, por volta de 2015, eu acreditava que a minha geração teria sido, talvez, a última empenhada na luta das mulheres. Até que um vozerio, marchas, protestos, campanhas na rede e meninas na rua se aglomeraram, gritando diante da ameaça de retrocesso que representava a aprovação do Projeto de Lei 5069/2013, que dificultaria o acesso de vítimas de estupro ao aborto legal. (HOLLANDA, 2018, p. 11).

Portanto, para ela, o que despertou a quarta onda do feminismo no país foram tentativas de promover retrocessos legais sobre os direitos da mulher. Evidentemente que uma decisão legislativa não promove a emergência de um movimento. A vinculação com causas feministas certamente já existia entre as jovens que foram às ruas, havendo ali um acontecimento forte o suficiente para unir as múltiplas vozes e chamar um ativismo digital, que White (2010) denominou de clickativismo, para o ambiente urbano.

\footnotetext{
3 Movimento que surgiu como forma de protesto às declarações de um policial canadense de que as mulheres deveriam evitar vestirem-se como vadias para não serem estupradas. Em 3 de abril de 2011, ocorreu, em Toronto, a primeira Marcha das Vadias (Slut Walk), que depois se espalhou pelo mundo inteiro, inclusive no Brasil. Esse movimento reivindica autonomia das mulheres sobre seus corpos (TOMAZETTI; BRIGNOL, 2015).

${ }^{4}$ A noção de ética é aqui tomada na perspectiva dos trabalhos de Foucault (2004b), a saber: uma relação do serconsigo.
}

Práxis Educativa, Ponta Grossa, v. 14, n. 3, p. 1188-1209, set./dez. 2019 Disponível em: <http://www.revistas2.uepg.br/index.php/praxiseducativa $>$ 
Segundo esse autor, o clickativismo é a morte do ativismo e somente sua superação poderá ressuscitar lutas políticas significativas. Segundo White (2010):

\begin{abstract}
Ao promover a ilusão de que navegar na web pode mudar o mundo, o clickativismo é para o ativismo, como o McDonalds faz para uma refeição lenta. Pode parecer comida, mas os nutrientes vivificantes desapareceram há muito tempo. Trocando a substância do ativismo por chavões reformistas que se saem bem em testes de mercado, os clicktivistas prejudicam todo movimento político genuíno que eles tocam. [...]. Suas campanhas de marketing ineficazes espalham o cinismo político e desviam a atenção de movimentos genuinamente radicais. A passividade política é o resultado final da substituição da crítica política saliente pela lógica da publicidade. (WHITE, 2010, n.p., tradução nossa).
\end{abstract}

Considerando as colocações de White, é possível efetivamente identificar, como o faz Hollanda (2018), a emergência da quarta onda de feminismo com os protestos que tomaram conta das ruas do Brasil em 2015. O feminismo, tal como outros movimentos sociais, só se tornaria, nessa perspectiva, potente ao ganhar a rua ${ }^{5}$. Os protestos contra o PL 5069/2013, que dificultava o atendimento a mulheres vítimas de violência sexual e restringia o acesso a métodos contraceptivos, tomaram as ruas de muitas cidades brasileiras em novembro de 2015 e contaram com milhares de participantes. Além desse protesto contra o PL 5069/2013, outros eventos feministas tomaram as ruas em 2015. Brasilia assistiu à Marcha das Mulheres Negras, com mais de 50.000 participantes, e à Marcha das Margaridas, que reuniu 70.000 trabalhadoras do campo ${ }^{6}$.

Entretanto, em nosso entendimento, o ativismo mediado pela rede não recai necessariamente no que White (2010) chama de clickativismo na medida em que se encarna na vida cotidiana, modificando modos de vida e formas de relacionamento. Aqui, estamos de acordo com o coletivo Não me Kahlo (2016) que considera não ser possível uma divisão entre um "feminismo real" e um "feminismo de internet", em que o segundo teria pouca potência e significância. Diferentemente dos movimentos que visam a mudar a política institucionalizada do Estado, o feminismo visa a transformar as relações de cada uma e cada um consigo e com os outros, o que tornar o ativismo digital um importante instrumento de disseminação das ideias feministas que irão transformar os modos de vida.

Assim, no mesmo ano de 2015, hashtags como \#Me'Too \#PrimeiroAssédio, \#MeuAmigoSecreto e \#AgoraÉqueSãoElas popularizaram-se, contribuindo para o debate e despertando a atenção para pautas assumidas pelo movimento feministas: preconceito, sexismo, assédio em suas diversas formas. Em relação às hashtags, estamos de acordo com Feixa, Fernández-Planells e Figueras-Maz (2016), os quais afirmam:

Tanto en Twitter como otras redes sociales como Instagram o más recientemente, Facebook, los distintos hashtags han expandido mensajes de toda índole creando tendencias sociales inmediatas. Podemos decir, pues, que el hashtag prefigura una nueva fase de la sociedad red, caracterizada por el surgimiento de la web social, una de cuyos rasgos centrales es la indexación (clasificación numérica y temática) de los sujetos participantes según afinidades sociales, ideológicas o culturales, así como la multiplicación exponencial de las capacidades de conectividad y colaboración entre ellos. (FEIXA; FERNÁNDEZ-PLANELLS; FIGUERAS-MAS, 2016, p. 111).

\footnotetext{
${ }^{5}$ É importante notar que não apenas pautas libertárias ou de esquerda se consolidam quando tomam as ruas. Os protestos de 2013, que se iniciaram com um movimento de esquerda contra o aumento das passagens dos ônibus urbanos, foram capturados pela direita, ou melhor, pela extrema direita ao apelarem para manifestações nas ruas que superaram o clickativismo. Cabe notar que um dos principais grupos que ajudou a alavancar a ascensão da extrema direita no Brasil chamava-se \#VempraRua.

${ }^{6}$ Esse foi considerado pela imprensa brasileira como o ano das mulheres, em razão das ações que iniciaram no espaço virtual e tomaram as ruas, posteriormente. Ver: http://agenciabrasil.ebc.com.br/direitoshumanos/noticia/2015-12/2015-o-ano-das-mulheres. Acesso em: 23 mar. 2019.
}

Práxis Educativa, Ponta Grossa, v. 14, n. 3, p. 1188-1209, set./dez. 2019 Disponível em: <http://www.revistas2.uepg.br/index.php/praxiseducativa > 
Cabe destacarmos que, apesar de ter eclodido com força no Brasil em 2015, desde 2010, já é possível mapear sinais dessa nova onda em manifestações públicas. Em 2011, ocorreu a primeira Marcha das Vadias no país, apenas poucos meses da marcha original, que se deu em abril do mesmo ano no Canadá. Essa forma de protesto teve continuidade em várias cidades brasileiras nos anos posteriores (HOLLANDA; BOGADO, 2018).

Essa quarta onda do feminismo assume as características de outros ativismos contemporâneos: horizontalidade e recusa a lideranças, priorizando os coletivos. Apesar da multiplicidade de correntes do feminismo atual, que muitas vezes resulta em duros embates, a questão que unifica as diversas correntes e que se coloca como pauta primeira é a violência contra a mulher. Além disso, as mobilizações sobre o tema muitas vezes não cabem nas fronteiras nacionais. Na América Latina, as máximas "Ni una a menos" ou "Nenhuma a menos", que começaram a circular nas redes sociais após os casos de feminicídio de duas jovens argentinas, já mobilizaram, desde 2015, passeatas e protestos em países como Brasil, México, Peru e Chile.

No centro desses movimentos, encontra-se o corpo, tanto como objeto de reivindicações, quanto como instrumento de protesto. Conforme Sorj e Gomes (2014), é um corpo-bandeira, que se desnuda, se pinta, se marca para mostrar a todos e todas que é livre para fazer o que deseja.

Ainda que ganhar as ruas seja importante para consolidar o ativismo feminista, a quarta onda faz intenso uso das redes sociais, termo utilizado para descrever diversificados "agrupamentos sociais online", firmados a partir de interesses comuns (MARTINO, 2014, p. 58). O próprio chamamento para a rua, o fomento da insatisfação em relação à condição feminina, tudo isso passa pela internet. Para Castells (2013, p. 10), as redes fornecem a plataforma tecnológica necessária para aglutinar as forças da rebelião.

Um instrumento importante para a mobilização dos afetos que conectam as mulheres ao feminismo são as autonarrativas. No caso do feminismo, materializaram-se diversas campanhas virais que promoveram a identificação das mulheres, como as já citadas \#MeToo e \#MeuPrimeiroAssedio. Essas campanhas trouxeram narrativas que eram pessoais, mas eram políticas. Eram singulares, mas também eram coletivas. Poderia ter acontecido com qualquer uma e com todas. A ressonância dessas histórias não apaga as diferenças, mas fomenta a empatia e sororidade $^{7}$ (HOLLANDA; COSTA, 2018). Essas campanhas mobilizaram brasileiras de todas as regiões a replicarem posts em redes como Facebook e Twitter, denunciando assédios sofridos na infância e na adolescência e, também, práticas de violência de gênero promovidas por homens de seu ambiente trabalho e/ou familiar. Assim, pelas plataformas virtuais, as mulheres unem-se para denunciar as violências de cada dia.

Entretanto, é importante perceber que, para o funcionamento dos movimentos sociais atuais, entre eles o feminismo, não se coloca uma escolha entre o digital e a rua, mas formas de articulação entre ambos. Não existe entre esses dois níveis de funcionamento uma relação de disputa ou antagonismo, mas de continuidade e complementaridade. Os movimentos que ficam apenas no âmbito da internet não conseguem se fortalecer e não conseguirão vitórias (WHITE, 2010). Malini e Antoun (2013), ao analisarem o ciberativismo, já afirmaram que a rede e a rua se interpenetram nas revoltas do século 21. A rede conecta cérebros, espalha afetos e fornece o combustível que irá incendiar as ruas. Também é pela rede que se coordena a revolta.

\footnotetext{
7 Sororidade significa uma relação de empatia e companheirismo entre mulheres. Sua origem está no latim sóror (irmãs), sendo um contraponto ao termo fraternidade, que se originou de frater (irmão).
}

Práxis Educativa, Ponta Grossa, v. 14, n. 3, p. 1188-1209, set./dez. 2019 Disponível em: <http://www.revistas2.uepg.br/index.php/praxiseducativa> 
As formas de acesso às redes nos tempos atuais por meio de dispositivos móveis corroboram a articulação entre o mundo físico e o digital, uma vez que é possível estar conectado o tempo todo, enquanto são realizadas ações e interações presenciais. Como destaca Martino (2014, p. 58), "[...] assim como o mundo real é levado para as redes sociais digitais, as discussões online têm potencial de gerar atitudes e ações no mundo físico". É importante destacar que, nos últimos anos, as tecnologias digitais tornaram-se mais acessíveis mesmo para as camadas mais pobres da população, principalmente pela popularização dos smartphones.

As narrativas em rede permitem, ainda, que se formem diferentes representatividades feministas. Feminismo lésbico, feminismo trans, feminismo negro, feminismo e maternidade, feminismo e corpos gordos são algumas vertentes importantes da atualidade. A rede permite que grupos se encontrem e discutam online, amadurecendo ideias e construindo pautas próprias. Com frequência, esses coletivos que se tecem no digital têm encontros presenciais, como festas, manifestações de ruas e reuniões.

Um outro ponto que é importante marcar é que a quarta onda se caracteriza menos como um movimento de protesto (apesar de também haver esse tipo de manifestação) e mais como um movimento que visa transformações culturais (HOLLANDA; COSTA, 2018). Essas mudanças devem se apoiar na construção de práticas discursivas que contestem e desconstroem práticas patriarcais. Para difundir essa discursividade, a rede é especialmente útil. Esse novo ativismo privilegia a ação direta dos atores sociais, orientados por seus próprios valores e independentes de instituições. A quarta onda do feminismo é fracamente institucionalizada e a maioria das mulheres que se narram como feministas não tem vinculação formal a nenhum coletivo, o que fica evidenciado nas narrativas das estudantes pesquisadas.

A divulgação das ideias do novo feminismo dá-se principalmente por redes sociais: páginas no Facebook, perfis no Twitter, no YouTube ou no Instagram e em blogs. Muitas mulheres, principalmente as mais jovens, têm sua inserção no feminismo por aí. A youtuber Jout, que, em março de 2019, contava com 2,1 milhões de seguidores, utiliza uma linguagem leve e engraçada para falar de feminismo e tem capturado a atenção de muitas mulheres para o tema. A partir da descrição de situações cotidianas, já vivenciadas por muitas mulheres (inclusive por ela mesma), a exemplo do uso de maquiagem e/ ou de determinadas roupas, Jout tensiona temas como relacionamentos abusivos, aborto, representatividade política.

Também a campanha Vamos juntas, criada pela jornalista Babi Souza, pode ser identificada com o feminino da quarta onda. $\mathrm{O}$ medo de Babi em atravessar à noite um parque da cidade transforma-se em um post no Facebook, convidando outras mulheres que fazem o mesmo trajeto que o seu a "irem juntas", a fim de protegerem-se de quaisquer violências. Em 20 dias, a angústia pessoal de uma jovem chegou ao conhecimento de 100 mil pessoas e, em poucos dias, transformara-se em uma campanha de união entre as mulheres que circulam pelos centros urbanos.

Valemo-nos de um vídeo de Jout e do site do Vamos juntas como disparadores do grupo de discussão entre alunas concluintes do Ensino Fundamental, em uma escola pública localizada na periferia de Porto Alegre, com o objetivo de discutir sua relação com o feminismo na Contemporaneidade.

\footnotetext{
${ }^{8}$ Ver <https://www.movimentovamosjuntas.com.br/index.php/o-vamos-juntas>. Acesso em: 23 mar. 2019.
} 


\section{Os marcos metodológicos}

Conforme destacamos anteriormente, a presente análise deriva de uma pesquisa qualitativa sobre culturas juvenis contemporâneas em escolas localizadas em periferias urbanas nas cidades de Porto Alegre (RS) e Canoas (RS). Segundo Denzin e Lincon (2006), uma pesquisa qualitativa consiste em um conjunto de práticas materiais e interpretativas utilizadas para dar visibilidade ao objeto de estudo e, dessa forma, o trabalho analítico refere-se aos processos de interpretação e de significação, afastando-se das mensurações e das relações causais entre variáveis.

Anterior ao grupo de discussão sobre feminismos na Contemporaneidade, já havíamos realizado observações ao longo de diferentes momentos da rotina escolar: entrada e saída da instituição, espaços de recreio e ao longo de situações de sala de aula, sendo os registros de tais momentos explanados em diário de campo. Aplicamos ainda um questionário fechado para a turma das jovens (alunos e alunas responderam), que tematizava sobre distintas dimensões da condição juvenil e organizamos grupos de discussão com estudantes, a fim de compreender melhor algumas dessas dimensões. As repostas dadas pelas jovens sobre os impeditivos para a realização de práticas de lazer e/ou circulação nas ruas do bairro motivou a organização do encontro que origina o presente artigo. Assim como Babi Souza, percursora do movimento "Vamos juntas', as estudantes pesquisadas destacam a fragilidade frente a violência de gênero como razão para não circularem por determinados espaços de sua comunidade.

A partir dos questionários aplicados também foi possível elencar os principais sites que as alunas acessam e, ainda, a periodicidade com o qual faziam. Redes sociais tais como Whats App, Facebook e Instagram pontuavam como as preferidas das jovens, assim como a plataforma Youtube. Nesta, os canais sobre música, em específico de cantores de funk, pagode e sertanejo, moda, motos e jogos virtuais, eram os mais acessados pelas jovens estudantes.

De acordo com Weller (2013), os grupos de discussão colocam-se como metodologia válida para a obtenção de dados acerca do contexto social e das visões de mundo dos participantes da pesquisa, pois "[...] constituem uma ferramenta importante para a reconstrução dos contextos sociais e dos modelos que orientam as ações dos sujeitos" (WELLER, 2013, p. 58). Segundo a autora, tal metodologia passa a ser utilizada na pesquisa social empírica nos anos de 1950, por integrantes da Escola de Frankfurt; e apenas nos anos de 1980 acaba por ser aplicada nas pesquisas com juventude (WELLER, 2013).

Nesta estratégia investigativa, não há a preocupação de que haja concordância entre os participantes sobre determinado tema, mas o profícuo debate de opiniões e pontos de vista. Dessa forma, é a interação entre os participantes a característica que proporciona "força metodológica" ao grupo de discussão, como também reforça Callejo (2001) ao apontar que há nos grupos de discussão a ênfase na interação de grupo. Compartilhamos, ainda, com Meinerz (2011, p. 486), o entendimento de que a metodologia do grupo de discussão abre a possibilidade de escuta sensível, que não se fundamenta apenas em rigores teóricos para sua realização, uma vez que tal escuta é dependente da postura "política, afetiva e ética do pesquisador". Weller (2013) refere ainda, como uma característica vantajosa dos grupos de discussão, a possibilidade de os participantes sentirem-se mais à vontade, pelo fato de conhecerem-se.

O grupo de discussão que este artigo problematiza teve como disparadores o vídeo "Eu não preciso do feminismo!", protagonizado por Jout, e uma visita ao site Vamos Juntas, descrito anteriormente. Enquanto este último é produzido pela empresa criada por Babi Souza, visando a impulsionar negócios de mulheres, aquele foi publicado pelo canal da Revista Capricho no Youtube. A Capricho é conhecida (e consumida) entre jovens há mais de 60 anos e, assim como

Práxis Educativa, Ponta Grossa, v. 14, n. 3, p. 1188-1209, set./dez. 2019 Disponível em: <http://www.revistas2.uepg.br/index.php/praxiseducativa $>$ 
outras tantas publicações impressas, assume, nos dias atuais, espaço nas plataformas digitais e permite que seu público tenha acesso ao conteúdo em uma multiplicidade de meios. Ambas produções são de 2016.

Conforme destacamos anteriormente, ambos canais não estavam entre os mais acessados pelas jovens estudantes. No entanto, a escolha deles deu-se pelo fato de Jout, na atualidade, transitar por espaços midiáticos diversos, tais como programas de televisão e comerciais, não se limitando ao seu canal específico do Youtube. Tal fato que ratifica nossa afirmação está no reconhecimento da imagem da referida youtuber pelas jovens pesquisadas ao apresentarmos seu vídeo.

Já a Revista Capricho, bem como sua página da web, como verificamos por meio dos questionários, eram materiais conhecidos das jovens. No entanto a \#GirlPowerCH, na qual o vídeo de Jout está vinculado, organizada pela Revista Capricho e circulante no Youtube, não havia sido acessado por nenhuma das alunas. Além de apresentar linguagem acessível, ser protagonizado por uma personalidade conhecida das jovens, vale destacar que o vídeo em questão apresenta o maior número de visualizações entre os organizados sob \#GirlPowerCH, fatos que motivaram nossa escolha pelo referido material.

Já a rápida repercussão da campanha "Vamos juntas" nas redes sociais e nas mídias, no período em que fora organizada, mobilizou nossa escolha pelo site - produto da mesma campanha, organizada no segundo semestre de 2015. Interessou-nos, ao escolhermos o material, ouvir as jovens sobre a potência de uma mobilização, encabeçada por uma jovem que, assim como as estudantes da pesquisa, também tinha medo, receio de andar pelas ruas em razão das violências às quais mulheres estão expostas.

Ambos materiais não eram de conhecimento prévio das alunas e lhes foram apresentados em sequência, em grupo composto apenas pelas jovens, que foram convidadas à participar da pesquisa com sua turma, tal como descrevemos anteriormente. ${ }^{9}$ Posterior à apresentação dos materiais, conduzimos o grupo de discussão focalizando com as jovens as dimensões e as (im)possibilidades do feminismo em nosso tempo, a partir da problematização dos materiais apresentados norteadas e pelas seguintes questões abertas, a saber: "O que é feminismo?"; "Onde e quando ouviu essa palavra pela primeira vez?"; "Qual a importância do feminismo"; e, ainda, "De que forma o feminismo pode (ou não) mudar a sociedade atual?". Vale destacarmos que tais questões eram norteadoras e que as respostas das jovens encaminharam outras problematizações. Toda a atividade (apresentação dos vídeos e grupo de discussão) transcorreu por cerca de 40 minutos.

É importante apontarmos que todas as participantes afirmaram conhecer o termo "feminismo", bem como a sua importância para a construção de ações para a defesa dos direitos das mulheres. Algumas afirmaram que tomaram conhecimento do assunto na escola, a partir das aulas de Filosofia. No entanto, a maior parte do grupo citou o espaço virtual, em especial as redes sociais, como espaço em que tiveram contato pela primeira vez com o termo, em detrimento aos veículos da grande mídia (jornais, televisão), que quase não foram citados. Logo, são as publicações do Youtube, as postagens no Facebook e Twitter, de amigos, conhecidos e/ou artistas, que franqueiam o acesso a esse tipo de conteúdo às jovens. Valeria problematizarmos (mas não será possível no escopo deste artigo) quais as discursividades circulam nas postagens sobre o

\footnotetext{
${ }^{9}$ Todos os encontros ocorreram nas dependências da escola, no turno de aula das turmas participantes.
} 
tema acessadas pelas jovens. Apresentamos, a seguir, três focos de análise que foram construídos a partir dos dados produzidos no grupo de discussão ${ }^{10}$.

\section{O que elas querem é poder lutar pelos direitos delas! - feminismos para quê?}

Após a exibição dos disparadores, abrimos o debate entre as jovens. Participativas, destacaram seus entendimentos sobre feminismo, repercussões do movimento em suas vidas e as (im)possibilidades e os modos de organização entre mulheres. Em suas palavras:

A. C.: Eu acredito que o feminismo seja para as mulheres poderem ter escolha na vida delas, não necessariamente poder fazer tudo que o homem faz igual, mas elas poderem ter escolha de fazer o que elas quiserem. Tipo que nem tu vê as pessoas... é mais ou menos que nem tu vê na escola dizer: a então quero ver mulher carregar pacote de cimento que nem homem faz. Tipo, não. Feminismo é a mulher fazer o que ela quiser, não fazer igual a homens.

T.: É tipo uma luta entre mulheres, é pelo que ela quer, o que ela pode escolher [...]. Feminismo é lutar contra os preconceitos que a mulher tem a cada dia [...]. É dar força pra mulher quando ela é assediada na rua ou também no trabalho, porque acontece muito no dia a dia, é tipo, é uma força que as mulheres tem pra lutar contra isso.

Apesar de relacionarem o discurso do feminismo à luta pela igualdade de gênero, a insegurança de andar nas ruas e a exposição à violência extrema provocada pela condição feminina são questões destacadas pelas estudantes como um dos fatores mobilizadores para a organização entre as mulheres. O que emerge desse grupo de discussão corrobora a afirmação de Hollanda (2018), de que o feminismo atual tem como foco principal a violência. É interessante destacar que as jovens se identificam com o discurso sobre violência de gênero pelo viés da insegurança das ruas: o medo do assalto, da violência sexual, da agressão pública promovida por um grupo rival (de homens ou de mulheres). Não há uma identificação, a partir das narrativas das jovens, com a violência no âmbito privado, nas relações afetivas ou referências aos recentes casos de feminicídio.

Pode-se pensar que as condições de vidas das jovens fomentem a reverberação dessa discursividade. Nas periferias urbanas, de um modo geral, a segurança pública convive com práticas ilícitas, como o tráfico de entorpecentes. A própria (in)segurança dos habitantes dessas regiões é constituída, muitas vezes, pelo relacionamento que eles estabelecem com os "poderes paralelos", ou seja, com os representantes do tráfico, ou do crime organizado (VARGAS, 2015). Os próprios "bondes" são destacados pelas jovens como grupos que podem agredir e/ou garantir a segurança. Em suas palavras:

R.: Eu acho, professora, na minha opinião, [o feminismo] uma boa coisa no caso porque tem mulher que tem medo de andar... Eu tenho medo de andar aqui na vila... de noite tenho medo de ser assaltada não por ser assaltada, mas sim pelo medo de ser abusada sexualmente, de ser agredida de qualquer forma, toda mulher tem esse medo.

B.: Eu tenho medo de ser sequestrada. Tenho medo de quando tô andando, passa aquele carro devagarzinho e vai parando...

R.: Tem grupos de mulheres que se juntam pra não andar sozinha, mas também tem grupos que se juntam pra ferir outras mulheres ou outras pessoas ...ou fazer coisas para pessoas indefesas na rua tipo... Assim como tem mulheres que gostam de se proteger, tem mulheres que gostam de agredir as pessoas indefesas.

Pesquisadora: Tipo bonde?

${ }^{10}$ Por razões éticas, as jovens são identificadas apenas pela primeira letra de seus nomes.

Práxis Educativa, Ponta Grossa, v. 14, n. 3, p. 1188-1209, set./dez. 2019 Disponível em: <http://www.revistas2.uepg.br/index.php/praxiseducativa $>$ 
Feminismos e redes sociais: (in)ações e (im)possibilidades de jovens de periferia urbana

R.: Exatamente. Aqui no colégio, professora, tem bonde! Se juntou três via whats... pode ser "né"...

Pode-se pensar que as mulheres da periferia de outros tempos, assim como as jovens da periferia de hoje, escapam do estereótipo de "sexo frágil"". Segundo Soihet (1997), pesquisadora de gênero alinhada às teorizações críticas:

As mulheres populares, em grande parte, não se adaptavam às características dadas como universais ao sexo feminino: submissão, recato, delicadeza, fragilidade. Eram mulheres que trabalhavam e muito, em sua maioria, não formalmente casadas, brigavam na rua, pronunciavam palavrões, fugindo, em grande escala, aos estereótipos atribuídos ao sexo frágil. (SOIHET, 1997, p. 367).

Apesar de identificarem no feminismo a possibilidade de fortalecimento para o embate às agressões mais comuns de seu cotidiano, as estudantes também reverberam discursos de luta contra o machismo, que silenciaria suas vozes.

B.: Eu acho que é bom, que é bom por elas se juntarem, as mulheres se juntarem e fazerem! Mas é ruim porque tipo isso não precisava acontecer. [...] se os homens tivessem a cabeça mais aberta e aceitassem que isso tudo está acontecendo, que os tempos são outros e que a mulher, hoje em dia, tem muito mais opção de escolha e eles não precisavam fazer isso [...]. Então eu acho que se os homens não pensassem dessa forma, acho que não precisaria existir esse tipo de coisa.

R: Exatamente, no caso essas pessoas que querem agredir elas não querem que (as mulheres) lutem pelos seus direitos. Elas querem que as pessoas continuem do jeito que estão, elas não querem no caso que as mulheres [...], as pessoas que se juntam para agredir as mulheres, elas não querem que as mulheres possam falar entendeu, possam lutar pelos seus direitos.

No entanto, vale mais uma vez destacarmos que as jovens reconhecem as proibições de livre expressão, as agressões físicas, a violência sexual consumada como práticas de violência de gênero. Os insultos, os gracejos inoportunos, os relacionamentos abusivos e as disparidades no mercado de trabalho não são relacionados por elas como problemáticas que atingem as mulheres, tampouco como pautas do discurso feminista. Apesar de as participantes reconhecerem a importância do feminismo para melhorar as condições de vida das mulheres, elas não identificam a necessidade de participar de grupos organizados que lutem por causas feministas.

\section{“Toda a escolha que a gente faz vai do nosso pensamento": organizar-se sem organizações}

Para as estudantes, a sua identificação com o feminismo independe da participação ou da filiação em um grupo e/ou coletivo, o que vai ao encontro das discussões já apresentadas de Hollanda e Costa (2018). O simples reconhecimento de valor nos ideais de igualdade de gênero, de amplificação de direitos às mulheres, permite que qualquer uma (ou qualquer um) considere-se como feminista. Se, em outros tempos, os feminismos concretizavam-se pela organização de grupos e de coletivos que se encontravam periodicamente para discutir, panfletar, protestar; nos tempos atuais, essa condição transforma-se, como as estudantes deixam claro a seguir:

\footnotetext{
${ }^{11}$ Embora reconheçamos a importância das discussões sobre a interseccionalidade entre gênero e raça, o recorte desta pesquisa e os dados produzidos não permitem desenvolver análises nesse sentido. Portanto, a questão da racialização feminina não será abordada neste artigo.
} 
Pesquisadora: E vocês acham que precisa ter uma organização, que as mulheres para serem feministas precisam fazer parte de algum grupo, de alguma organização, de alguma comunidade?

A.C.: Basta apenas elas terem o pensamento de que querem ter opção, de escolher por elas mesmas, isso já se torna um movimento social! O fato de elas mesmas quererem, de poder decidir, isso já te torna feminista.

Pesquisadora: Então acham que não precisa participar de algum grupo?

R: Não, porque toda a escolha que a gente faz vai do nosso pensamento, então se a mulher acha que da forma que ela "tá" agindo "tá" certo, "tá" certo! Mas eu não preciso criar um grupo de mulheres feministas pra dizer, pra mostrar que eu sou feminista. Se a minha consciência "tá" limpa, tudo vai da escolha de cada um.

As formas de manifestação política são cada vez mais diferentes daquelas da Modernidade. A ordem das instituições, a hierarquia das posições e as orientações ideológicas são substituídas por relações éticas fugazes e contingentes. De acordo com o Comitê Invisível ${ }^{12}$ (2016, p. 18): "Se organizar nunca quis dizer se filiar a uma mesma organização. Se organizar é agir segundo uma percepção comum, em qualquer nível que seja". Portanto, a não filiação dessas jovens a coletivos não significa que não pertençam a um movimento político, pois elas unem-se a tantas outras mulheres na reivindicação do direito de não sofrerem violências motivadas pelo seu gênero. Ainda segundo esse coletivo, as insurreições contemporâneas "[...] não partem mais de ideologias políticas, mas de verdades éticas" (COMITÊ INVISÍVEL, 2016, p. 53). As insurreições contemporâneas ligam cada um a si mesmo e a seu entorno na construção de formas desejáveis de vida. E é justamente isso que essas jovens reivindicam: outras formas de vida que lhes garantam mais liberdade e autonomia.

As falas das participantes remetem a uma perspectiva de organizar-se sem organização por reconhecerem que o feminismo é algo coletivo, mesmo na dispersão das vidas singulares. Quando uma das jovens faz referência ao "grupo de pessoas feministas", conforme mostra o excerto a seguir, não podemos afirmar que ela compreenda esse grupo como um coletivo organizado, mas, sim, como uma designação que engloba de modo genérico os sujeitos que se identificam com as ideias feministas e que operam conjuntamente visando à transformação do mundo e das relações.

B.: Eu concordo que a gente não precisa ser de algum grupo, de alguma associação pra ser... pra falar que a gente é feminista, mas ter um pensamento em querer mudar as coisas. Acho que tem muita pessoa que é feminista e que não fala $E$ por isso as pessoas acham que não é, entendeu... que a pessoa não é feminista, e daí as pessoas que são feministas, o grupo de pessoas que são feministas diminui entendeu e daí isso se torna... tipo as pessoas ficam... o grupo de feministas fica mais fraco pela quantidade de pessoas que tem o grupo.

"Falar" que se é feminista não necessariamente seja fazer isso nas ruas, no espaço público ou em um coletivo. Post, curtidas, comentários em páginas de redes sociais já bastariam para identificar alguém como feminista. E, aqui, vale destacarmos que, em outro momento da pesquisa com esse grupo, em que se discutiu o uso da internet, nenhuma das jovens afirmou ter como uma de suas preferências canais e/ou páginas voltadas à divulgação do feminismo. Contudo, foi no espaço virtual em que algumas delas ouviram falar pela primeira vez em feminismo:

\footnotetext{
12 O Comitê Invisível é um grupo anônimo de intelectuais ativistas que vem produzindo obras para tensionar o pensamento político contemporâneo. Segundo eles mesmos, ao referirem-se ao livro Aos nossos amigos, "[...] este texto é editado simultaneamente em oito línguas e sobre quatro continentes. Se nós estamos por todo o lado, se nós somos legiões, temos agora que nos organizar, mundialmente” (COMITÊ INVISÍVEL, 2016, p. 20).
}

Práxis Educativa, Ponta Grossa, v. 14, n. 3, p. 1188-1209, set./dez. 2019 Disponível em: <http://www.revistas2.uepg.br/index.php/praxiseducativa > 
Feminismos e redes sociais: (in)ações e (im)possibilidades de jovens de periferia urbana

T: Foi no Youtube, na Kefera...

A.C.: Hum, acho que foi pelo Facebook, redes sociais, essas coisas porque sempre vivem postando sobre isso.

J.: Ah, eu conheci essa palavra no Twitter.

Esse ambiente digital que é capaz de levar o feminismo até a periferia também tem a potencialidade de bloquear os fluxos em outros movimentos. Os enunciados que estão associados no senso comum, e que circulam nas redes sociais, ao movimento feminista são pontuados pelas jovens como possibilidades para que as pessoas não se identifiquem com essa causa e, por conseguinte, diminuir sua potência. A discursividade que produz as feministas como lésbicas e/ou assexuadas, bem como descuidadas com seus corpos, ainda circula com força na sociedade, segunda as jovens. Segundo elas, existe uma forte rejeição a esse discurso.

A. C. Fora que também esse movimento feminista, ele "tá" meio manchado pelas mulheres que fazem ufanismo, porque tipo quando tu falas assim: "Eu sou feminista", a pessoa já pensa "Bah, ela tem sovaco cabeludo, ela deve odiar homem". [...]. Principalmente essas novas mulheres que não conhecem direito isso, começam a te julgar... a falar um monte de coisa: "Ai que não sei o que... que tu tem que... que isso aí é "falta de rola". Sei que começam a falar um monte de porcaria...

De acordo com o Comitê Invisível (2016), os movimentos de contrainsurreição contemporâneos apelam mais para a conquista dos corações do que para a conquista de territórios. Nesse sentido, produzir uma identidade de feministas com atributos que muitas mulheres rejeitam constitui-se em uma estratégia de dissuasão das mulheres em aderir ao feminismo, em produzir-se com um ethos feminista. A consolidação de enunciados que tornam as mulheres repulsivas a seus próprios olhos funciona como uma estratégia de enfraquecimento do feminismo.

As jovens participantes da pesquisa, como já mostramos, consideram importantes as pautas feministas e desejam vê-las propulsionadas e divulgadas, mesmo sem desejarem uma relação de pertença com os movimentos organizados. Na seção seguinte, discutimos as estratégias que elas apontam como eficazes para essa difusão.

\section{A rede, a rua e a escola}

Conforme destacamos anteriormente, a identificação das participantes da pesquisa com o movimento feminista não corresponde, necessariamente, à filiação, à participação delas em determinados grupos sobre o tema. Possivelmente, uma relação não institucionalizada com o feminismo seja aquela assumida pela maior parte das mulheres que se identificam com essa posição (HOLLANDA; COSTA, 2018). Contudo, mesmo sem a institucionalização das relações, muitas mulheres tomam contato com as discussões de grupos organizados por meio da internet, em especial por meio de redes sociais.

Durante o grupo de discussão, as alunas apontaram a importância de que as mulheres se organizem em grupos para reivindicar seus direitos, apesar de sua rejeição a uma filiação institucional. Foram justamente as redes sociais que surgiram como ferramenta para promover sua organização. 
Pesquisadora: E como esses grupos se organizariam? Ou como eles se organizam hoje? Vocês conhecem algum grupo assim? Alguma comunidade na internet?

A. C.: Seria por redes sociais, no caso não?

B.: Eu acho que tipo, a rede social é um espaço que dá liberdade pra fazer esse tipo de coisa, que tipo é o público grande que usa, "né"? Praticamente todo mundo hoje em dia, $99 \%$ das pessoas no mundo têm alguma rede social, independente de qual for entendeu, então eu acho que é um espaço muito amplo para as pessoas divulgarem esse tipo de coisa.

Segundo o excerto anterior, as redes sociais constituir-se-iam como um lugar de liberdade e de horizontalidade, capaz de produzir associações que subvertam a ordem da sociedade. Essa percepção era compartilhada por Castells (2013) em 2012, quando foi publicado pela primeira vez Redes da indignação e da esperança. Nessa obra, o autor escreve que as redes sociais "[...] são espaços de autonomia, muito além do controle de governos e empresas, que, ao longo da história, haviam monopolizado os canais de comunicação como alicerces de seu poder" (CASTELLS, 2013, p. 10). Malini e Antoun (2013), em 2013, apontavam censura ao compartilhamento em redes sociais como uma forma de controle das narrativas que haviam deixado de ser exclusividade dos grandes veículos de comunicação.

Contudo, desde então, assistimos à emergência de novas estratégias que visam sufocar as narrativas indesejáveis. A censura e o controle não são mais possíveis, a menos do bloqueio do fluxo de informações por governos autoritários. As novas estratégias consistem, justamente, na construção de outras narrativas para conquistar os corações. Essas narrativas, muitas vezes, apoiam-se nas chamadas fake news e são impulsionadas por bots ${ }^{13}$. Em seu livro seguinte, de 2017, Castells (2018) já apresenta um entendimento mais sombrio das redes sociais:

Num mundo de redes digitais em que todos podem se expressar não há outra regra além da autonomia e da liberdade de expressão, os controles e censuras tradicionais se desativam, as mensagens de todo tipo formam uma onda bravia e multiforme, os bots multiplicam e difundem imagens e frases lapidares aos milhares, e o mundo da pósverdade, do qual a mídia tradicional acaba participando, transforma a incerteza na única verdade confiável: a minha, a de cada um. A fragmentação da mensagem e a ambiguidade da comunicação remetem a emoções únicas e pessoais constantemente realimentadas por estratégias de destruição da esperança. Para que tudo continue igual. (CASTELLS, 2018, p. 28).

Mesmo sendo possível reconhecer que as redes sociais não sejam aquele paraíso de liberdade e de democracia que acreditávamos, é necessário reconhecer, porém, que elas ainda guardam o potencial de alavancar mobilizações. Contudo, como já discutimos antes, o clickativismo (WHITE, 2010) não será capaz de realizar transformações. É necessário articular a internet e a rua. E isso é reconhecido pelas participantes, quando uma delas indica a necessidade de encontros presenciais:

R.: É, no caso ajuda as mulheres que conhecem já o site né [...]. Quem não mexe muito em rede social ou alguma coisa, não conhecem o site mas no caso deveria fazer, como a maioria das pessoas faz hoje em dia tem gente que cria página no Face e faz um encontro pra divulgar a ideia delas.

Segundo Castells (2013), “[...] os movimentos sociais precisam abrir um novo espaço público que não se limite à internet, mas se torne visível nos lugares da vida social. É por isso que ocupam o espaço urbano [...]. Os espaços ocupados têm desempenhado papel importante na

13 Bots, forma reduzida de robot, são softwares que emulam ações humanas. Entre suas utilizações, destaca-se a disseminação de postagens por meio de redes sociais.

Práxis Educativa, Ponta Grossa, v. 14, n. 3, p. 1188-1209, set./dez. 2019 Disponível em: <http://www.revistas2.uepg.br/index.php/praxiseducativa > 
história da mudança social" (CASTELLS, 2013, p. 16). Para o autor, a proximidade física cria comunidades e confiança mútua, corroborando as discussões de White acerca do ciberativismo. Contudo, não está apenas nas redes sociais a aposta das participantes na difusão do feminismo; elas entendem que a escola também teria um papel importante.

B.: Acho que devia ter mais isso nas escolas, principalmente, na casa com os pais ou com os familiares.

A.C.: $\mathrm{O}$ difícil de ter com os pais é que muitos pais ou familiares nasceram de uma geração machista, ainda vão te bater ... dar um tapão na tua cara.

B.: É, exatamente, mas se a escola organizasse alguma coisa tipo uma reunião com os pais, pra conversar isso com os pais, porque tem muitos pais que não sabem disso, por serem com uma idade mais avançada, mas tipo idade não é o problema entendeu, o problema tá na cabeça das pessoas.

Esses excertos mostram que as participantes ainda acreditam que a escola possa ser um instrumento de transformação social, confiando mais nela do que na própria família. Nesse sentido, é possível compreender que essas alunas apoiam discussões sobre gênero no ambiente escolar, vendo aí uma possibilidade de construir novas formas de vida. Até mesmo a ONU sinaliza seu apoio a que o feminismo chegue à escola. Um de seus objetivos relacionados ao desenvolvimento sustentável é: "Alcançar a igualdade de gênero e empoderar todas as mulheres e meninas" (ONUBR, 2015, n.p.). Entre as ações propostas para atingir esse objetivo está a inserção na temática gênero nas escolas. Segundo a Organização das Nações Unidas para a Educação, a Ciência e a Cultura (Unesco), o braço da ONU para assuntos educacionais, "[...] a igualdade de gênero requer uma abordagem que assegure que meninas e meninos, mulheres e homens não apenas tenham acesso e completem os ciclos educacionais, mas que sejam igualmente empoderados na e por meio da educação" (UNESCO, 2019, n.p.).

As análises aqui apresentadas permitiram compreender que essas jovens de periferia estão sendo atravessadas por discursos feministas que modificam sua visão de mundo, sua relação consigo mesmas e com o seu entorno, mesmo que não haja uma vinculação institucional. Isso sugere que a discursividade feminista de quarta onda vem se espraiando de modo capilarizado, atingindo mulheres que em outros momentos não teriam sido tocadas.

\section{Encerrando brevemente}

\section{J. Eu acho que feminismo é uma luta por direitos para todos, não só mulheres, mas para todos.}

A partir da pesquisa, pudemos perceber que o feminismo vem se enraizando nos corações das mulheres de periferia. Concordamos com Hollanda (2018, p. 12) quando afirma que está emergindo "[...] uma nova geração política, na qual se incluem as feministas, com estratégias próprias, [...] valorizando mais a ética do que a ideologia, mais a insurgência do que a revolução". Essa geração de jovens mulheres pobres de periferia traz consigo a potência de uma insurgência pulsante. A insurgência não visa à vitória, mas a produção de subjetividades insurgentes. Aqueles que se insurgem tornam-se outros e vivem uma vida outra (FOUCAULT, 2004a).

Um fato que chamou atenção foi o desejo dessas jovens de que a escola traga o tema gênero para o currículo, contrariando os discursos de alguns grupos atuais que estão tentando reorientar as políticas educacionais no sentido de evitar que o que chamam de "ideologia de gênero" chegue às salas de aula. A Base Nacional Curricular Comum (BNCC), publicada entre 2017 e 2018, não se refere a esse tema por pressão de grupos conservadores. Entretanto, no 
Brasil, as Diretrizes Curriculares Nacionais (DCN) vigentes orientam que essa temática deve estar presente na escola e os Parâmetros Curriculares Nacionais (PCN) propõem que relações de gênero sejam tratadas como um tema transversal. Mais especificamente, os PCN (BRASIL, 1997) trazem que "[...] a discussão sobre gênero propicia o questionamento de papéis rigidamente estabelecidos a homens e mulheres na sociedade, a valorização de cada um e a flexibilização desses papéis".

Portanto, no momento, a temática gênero ainda deve ser contemplada pelos currículos. Fica aqui registrado o tensionamento hoje existente entre as disposições legais e as pressões de grupos políticos representantes das bancadas neopentecostais que têm, tanto no âmbito Federal como nos estados e municípios, contestado essas orientações. Essas pressões vêm causando, por vezes, constrangimentos e até a dispensa de docentes, fazendo com que já haja uma redução dessas discussões nas escolas. Entretanto, cabe destacarmos que a pressão de grupos conservadores religiosos para a retirada do tema do currículo escolar não conta com apoio da maioria da população. De acordo com pesquisa realizada pela organização Católicas pelo direito de decidir (2017), 84\% da população está de acordo que a escola discuta a igualdade entre homens e mulheres. Conforme coloca Hooks (2018), os movimentos feministas futuros precisam pensar na educação feminista como algo importante na vida de todo mundo.

Pode-se pensar que, em alguma medida, as redes têm produzido tais discussões, a exemplo dos materiais com que trabalhamos neste estudo. Embora não seja o ideal, esses artefatos podem, de algum modo, suprir o que as escolas não oferecerem. Vivenciamos um tempo de reconfiguração das formas de luta e/ou engajamento nas pautas sociais, antes filiadas às ideias de pertencimento político-ideológico e unicamente à presença física. Como diz Hooks (2018, p. 23), “[...] a política começou a ser aos poucos removida do feminismo. E prevaleceu a hipótese de que não importa o posicionamento político de uma mulher, [...], ela também pode encaixar o feminismo em seu estilo de vida". A quarta onda do feminismo caracteriza-se mais pela ética do que pela ideologia. $\mathrm{Na}$ atualidade, as jovens, como aquelas participantes da pesquisa, reconhecem-se como feministas sem a necessidade de filiação, pertencimento ou participação efetiva em algum coletivo. Basta pensar-se feminista para ser feminista. Tais jovens são exemplos da multiplicidade de ser/estar que mobilizam a geração \#, como destacam Feixa, FernándezPlanells e Figueras-Maz (2016, p. 115): "Es decir, la movilidad constante, la desvinculación de identidades sociales, culturales y profesionales fijas".

É importante, também, enfatizar que um grande número de estabelecimentos públicos de ensino, em cidades de médio e grande porte, está localizado em regiões de periferia urbana, fato que também impulsiona a organização deste estudo. Entretanto, vale pontuarmos que, na Contemporaneidade, o entendimento de periferia apenas como um espaço apartado dos centros das cidades e com regramentos específicos tem sido considerado insuficiente. De acordo com Freitas (2009, p. 35), deve-se utilizar o conceito de periferia “[...] para explicitar uma realidade urbana contemporânea, na qual é impossível separar o centro do entorno exclusivamente pela recorrência às características espaciais específicas". Ferreira e Costa (2010, p. 199) entendem que "[...] periferia urbana é favela, morro, conjunto habitacional, comunidade, etc.; são lugares onde o estereótipo da pobreza tem dado lugar a novas potências". A pobreza, por conseguinte, não se coloca apenas como falta, como déficit, mas como potência cultural e criativa, como problematizam Hardt e Negri (2016).

$\mathrm{Na}$ esteira de Moreira e Silva Junior (2010), acreditamos que estudar as periferias urbanas coloca-se como um caminho profícuo para a análise das práticas sociais constituídas pelos moradores que nelas habitam e também para compreensão dos discursos circulantes em tais espaços. Os feminismos também têm (re)configurações nos espaços das periferias urbanas, como

Práxis Educativa, Ponta Grossa, v. 14, n. 3, p. 1188-1209, set./dez. 2019 Disponível em: <http://www.revistas2.uepg.br/index.php/praxiseducativa> 
pode-se depreender neste estudo, não abarcando lutas por representação política ou por igualdade salarial. As lutas feministas, nas referidas regiões, representam as batalhas do cotidiano - a exemplo da violência, o que denota uma das tantas (im)possibilidades do movimento da Contemporaneidade.

\section{Referências}

AKOTIRENE, C. O que é interseccionalidade?. Belo Horizonte: Letramento: Justificando, 2018.

BRASIL. Arquivo Nacional. Federação Brasileira pelo Progresso Feminino. 2018. Disponível em: $\quad<$ http://brasilrepublicano.arquivonacional.gov.br/component/content/article/61conhe $\% \mathrm{C} 3 \% \mathrm{~A} 7 \mathrm{a}$-nosso-acervo/121-federacao-brasileira-pelo-progresso-feminino.html $>$. Acesso em: 17 mar. 2019.

BRASIL. Ministério da Educação. Parâmetros Curriculares Nacionais: apresentação dos temas transversais, ética. Brasília: MEC/SEF, 1997.

BRASIL. Tribunal Superior Eleitoral. Série inclusão: a conquista do voto feminino no Brasil. 2013. Disponível em: <http://www.tse.jus.br/imprensa/noticias-tse/2013/Abril/serie-inclusaoa-conquista-do-voto-feminino-no-brasil>. Acesso em: 17 mar. 2019.

CALLEJO, J. El grupo de discusión: introducción a una práctica de investigación. Barcelona: Ariel, 2001.

CASTELLS, M. Redes de indignação e de esperança: movimentos sociais na era da internet. Rio de Janeiro: Zahar, 2013.

CASTELLS, M. Ruptura. Rio de Janeiro: Zahar, 2018.

CATÓLICAS PELO DIREITO DE DECIDIR. Percepção sobre aborto e educação sexual. São Paulo: IBOPE, 2017. Disponível em: <http://catolicas.org.br/wpcontent/uploads/2017/10/Pesquisa-de-Opini $\%$ C3\%A3o-P\%C3\%BAblica-2017-CDD-e-

IBOPE-Percep $\% \mathrm{C} 3 \% \mathrm{~A} 7 \% \mathrm{C} 3 \% \mathrm{~B} 5$ es-sobre-aborto-e-educa $\% \mathrm{C} 3 \% \mathrm{~A} 7 \% \mathrm{C} 3 \% \mathrm{~A} 3 \mathrm{o}-$ sexual_3MB.pdf>. Acesso em: 17 mar. 2019.

COIMBRA, C. A sociedade civil frente ao estado militar: expressões de resistência. 2001. Disponível em: <https://app.uff.br/slab/uploads/texto49.pdf>. Acesso em: 17 mar. 2019.

COMITÊ INVISÍVEL. Aos nossos amigos: crise e insurreição. São Paulo: n-1, 2016.

CRENSHAW, K. Demarginalizing the intersection of race and sex: a black feminist critique of antidiscrimination doctrine. Feminist Theory and Antiracist Politics, Chicago, v. 140, n. 1, p. 139-146, 1989.

DAYRELL, J. A escola "faz" as juventudes? Reflexões em torno da socialização juvenil. Educação \& Sociedade, Campinas, v. 28, n. 100, p. 1105-1128, out. 2007. DOI: http://dx.doi.org/10.1590/S0101-73302007000300022 
DEL ROIO, M. et al. Tempos de ditadura militar: resistência e cultura. Cadernos CEDEM, Marília, v. 1, n. 1, p. 82-100, 2008.

DENZIN, N. K.; LINCOLN, Y. S. O planejamento da pesquisa qualitativa: teoria e abordagens. Tradução de Sandra Regina Netz. 2. ed. Porto Alegre: Artmed, 2006.

FEIXA, C.; FERNÁNDEZ-PLANELLS, A.; FIGUERAS-MAZ, M. Generación Hashtag. Los movimientos juveniles en la era de la web social. Revista Latinoamericana de Ciencias Sociales, Niñez y Juventud, Manizales, v. 14, n. 1, p. 107-120, jan./jun. 2016.

FERREIRA, H. P.; COSTA, M. J. S. R. Do local ao global: o serviço de radiodifusão comunitária e sua inserção no ciberespaço. In: SOBREIRA, H. G. (Org.). Educação, culturas e comunicação nas periferias urbanas. Rio de Janeiro: Lamparina, 2010. p. 197-210.

FOUCAULT, M. É inútil revoltar-se?. In: FOUCAULT, M. Ditos \& escritos: Ética, sexualidade, política. v. 5. Rio de Janeiro: Forense universitária, 2004a. p. 77-81.

FOUCAULT, M. Tecnologias de si. Verve, São Paulo, n. 6, p. 321-360, 2004b.

FREITAS, G. A cultura na (da) periferia e a periferia na (da) mídia. Políticas Culturais em Revista, Salvador, v. 2, n. 2, p. 34-49, 2009. DOI: http://dx.doi.org/10.9771/1983$\underline{3717 \text { pcr.v2i } 2.4273}$

FURIOSA. O que são as ondas do feminismo?. QG Feminista, 8 mar. 2018. Disponível em: $<$ https://medium.com/qg-feminista/o-que-s\%C $3 \%$ A3o-as-ondas-do-feminismo-

eeed092dae3a >. Acesso em: 17 mar. 2019.

HARDT, M.; NEGRI, A. Bem-estar comum. Rio de Janeiro: Record, 2016.

HOLLANDA, H. B. de. Introdução: o grifo é meu. In: HOLLANDA, H. B. de. Explosão feminista: arte, cultura, política e universidade. São Paulo: Companhia das letras, 2018. p. 11-19.

HOLLANDA, H. B. de; BOGADO, M. Rua. In: HOLLANDA, H. B. de. Explosão feminista: arte, cultura, política e universidade. São Paulo: Companhia das letras, 2018. p. 23-42.

HOLLANDA, H. B. de; COSTA, C. Rede. In: HOLLANDA, H. B. de. Explosão feminista: arte, cultura, política e universidade. São Paulo: Companhia das letras, 2018. p. 43-40.

HOOKS, B. O feminismo é para todo mundo: políticas arrebatadoras. Rio de Janeiro: Rosa dos Tempos, 2018.

LIPOVETSKY, G. Os tempos hipermodernos. São Paulo: Barcarolla, 2004.

MALINI, F.; ANTOUN, H. @internet e \#rua: ciberativismo e mobilização nas redes sociais. Porto Alegre: Sulina, 2013.

MANRIQUE, D. Paz e amor, 50 anos. El País, 4 ago. 2017. Disponível em: <https://brasil.elpais.com/brasil/2017/08/04/cultura/1501865756_160826.html>. Acesso em: 17 mar. 2019. 
MARTINO, L. M. S. Teorias das mídias digitais: linguagens, ambientes e redes. Petrópolis, Vozes: 2014.

MEDEIROS, K. "Todas as mulheres do mundo": um olhar sobre Leila Diniz e seu tempo. Revista de História da UEG, Morrinhos, v. 5, n. 2, p. 176-198, ago./dez. 2016.

MEINERZ, C. B. Grupos de Discussão: uma opção metodológica na pesquisa em educação. Educação \& Realidade, Porto Alegre, v. 36, n. 2, p. 485-504, maio/ago. 2011.

MEYER, D. E. E. Do poder ao gênero: uma articulação teórico-analítica. In: LOPES, M. J.; MEYER, D.; WALDOW, V. R. (Orgs.). Gênero \& saúde. Porto Alegre: Artes Médicas, 1996. p. 41-51.

MEYER, D. E. E. Gênero e educação: teoria e política. In: LOURO, G.; NECKEL, J. F.; GOELLNER, S. V. (Orgs.). Corpo, gênero e sexualidade: um debate contemporâneo na educação. Petrópolis: Vozes, 2003. p. 9-27.

MOREIRA, A. F. B.; SILVA JUNIOR, P. M. Periferias, sexualidades e educação para a sexualidade: desafios para as práticas curriculares. In: SOBREIRA, H. G. (Org.). Educação, culturas e comunicação nas periferias urbanas. Rio de Janeiro: Lamparina, 2010. p. 21-40.

NÃO ME KAHLO. \#MeuAmigoSecreto: feminismo além das redes. Rio de Janeiro: Edições de Janeiro, 2016.

ONUBR. Basta à violência contra as mulheres. 2010. Disponível em: <https://nacoesunidas.org/basta-a-violencia-contra-as-mulheres/>. Acesso em: 17 mar. 2019.

ONUBR. Igualdade de gênero. 2015. Disponível em: <https://nacoesunidas.org/tema/ods5/>. Acesso em: 17 mar. 2019.

PINTO, C. Feminismo, história e poder. Revista de Sociologia Política, Curitiba, v. 18, n. 36, p. 15-23, jun. 2010. DOI: http://dx.doi.org/10.1590/S0104-44782010000200003

PINTO, C. Uma história do feminismo no Brasil. São Paulo: Fundação Perseu Abramo, 2003.

RIBEIRO, D. Feminismo negro: para além de um discurso identitário. Cult, 9 jun. 2017. Disponível em: <https://revistacult.uol.com.br/home/feminismo-negro-para-alem-de-umdiscurso-identitario/>. Acesso em: 17 mar. 2019.

SOIHET, R. Mulheres pobres e violência no Brasil urbano. In: DEL PRIORE, M. (Org.). História das mulheres no Brasil. São Paulo: Contexto, 1997. p. 362- 400.

SORJ, B.; GOMES, C. Corpo, geração e identidade: a Marcha das vadias no Brasil. Sociedade e Estado, Brasília, v. 29, n. 2, p. 433-467, maio/ago. 2014. DOI: http://dx.doi.org/10.1590/S0102-69922014000200007

THIOLLENT, M. Maio de 1968 em Paris: testemunho de um estudante. Tempo Social, São Paulo, v. 10, n. 2, p. 63-100, out. 1998. DOI: http://dx.doi.org/10.1590/S0103$\underline{20701998000200006}$ 
TOMAZETTI, T. P.; BRIGNOL, L. D. O feminismo contemporâneo a (re) configuração de um terreno comunicativo para as políticas de gênero na era digital. In: ENCONTRO NACIONAL DE HISTÓRIA DA MÍDIA, 10., 2015, Porto Alegre. Anais... Porto Alegre: UFRGS, 2015. p. 115.

UNESCO. Education and gender equality. 2019. Disponível em <https://en.unesco.org/themes/education-and-gender-equality>. Acesso em 17 mar. 2019.

VARGAS, J. R. de. O que ouço me produz e me conduz? A constituição de feminilidades contemporâneas de jovens contemporâneas no espaço escolar da periferia. 2015. 182 f. Tese (Doutorado em Educação) - Universidade Federal do Rio Grande do Sul, Porto Alegre, 2015.

WELLER, W. Grupos de discussão: aportes teóricos e metodológicos. In: WELLER, W.; PFAFF, N. Metodologias da pesquisa qualitativa em educação. 3. ed. Petrópolis: Vozes, 2013. p. 54-66.

WHITE, M. Clicktivism is ruining leftist activism. 2010. Disponível em: <https://www.micahmwhite.com/clicktivism-seminal-essay>. Acesso em: 17 mar. 2019.

Recebido em 31/03/2019

Versão corrigida recebida em 22/08/2019

Aceito em 23/08/2019

Publicado online em 02/09/2019 